\title{
GROWTH PERFORMANCE AND SURVIVAL OF LARVAE OF Ompok pabda PRODUCED FROM VITAMIN E TREATED FEMALE BROODFISH
}

\author{
M. F. A. Mollah and M. N. Sarowar \\ Department of Fisheries Biology and Genetics, Bangladesh Agricultural University \\ Mymensingh-2202, Bangladesh
}

\begin{abstract}
An experiment was conducted to observe growth performance and survival of the larvae produced from the brood fish of Ompok pabda treated with 4 dietary levels of vitamin E for 90 days viz. 0 (served as control), 50, 100 and 150mg vitamin $\mathrm{E} / \mathrm{kg}$ feed under 4 treatments i.e. treatment $\mathrm{T}_{1}, \mathrm{~T}_{2}, \mathrm{~T}_{3}$ and $\mathrm{T}_{4}$. After the feeding trials, the brood fish were induced to breed with equal dose of PG extract i.e. 12 and $18 \mathrm{mg} / \mathrm{kg}$ body weight for male and female respectively and subsequently larvae were produced. The experiment was started with 5 days-old larvae having an average weight and length of $21.4 \pm 8.6 \mathrm{mg}$ and $13.8 \pm 2.49 \mathrm{~mm}$ respectively in 16 bowls of $10 \mathrm{l}$ capacity divided into 4 treatments corresponding to the broods fish having 3 replications each with 100 larvae in each bowl i.e. 10 larvae per liter. After rearing for 28 days with live-food tubificid worms the highest growth rate in terms of weight $(609.13 \pm 15.20 \mathrm{mg})$ and length $(86.70 \pm$ $1.84 \mathrm{~mm})$, gain in weight $(587.78 \pm 15.27 \mathrm{mg})$ and length $(72.98 \pm 1.81 \mathrm{~mm})$, specific growth rate $(30.36 \pm 0.12 \%)$, health condition $(16.63 \pm 0.69 \mathrm{mg} / \mathrm{mm})$ and survival $(83.25 \pm 2.87)$ were showed by the larvae produced from brood fish fed with $100 \mathrm{mg}$ vitamin $\mathrm{E} / \mathrm{kg}$ feed (treatment $\mathrm{T}_{3}$ ) while poorest was observed by the larvae produced from brood fish fed $150 \mathrm{mg}$ vitamin $\mathrm{E} / \mathrm{kg}$ feed. The results imply that inclusion of $100 \mathrm{mg}$ vitamin E/ $\mathrm{kg}$ feed in the diet of O. pabda brood fish is best for enhancing growth and survival of larvae indicating that vitamin $\mathrm{E}$ has a positive impact. The results also suggest that inclusion of higher level of vitamin $\mathrm{E}$ in the diet exerts an antagonistic effect on the produced larvae.
\end{abstract}

Key words : Vitamin E, Ompok pabda, Larvae, Growth rate, Survival

\section{INTRODUCTION}

Among many indigenous fishes of Bangladesh, O. pabda locally known as pabda, a small freshwater catfish belonging to the family Siluridae of the order Siluriformes (Siddiqua et al., 2000) is a highly priced and one of the most sought after fishes. It can thrive in all types of freshwater habitats, especially in rivers, canals, beels, swamps, floodplains and ponds. It is also geographically distributed in India, Pakistan, Afghanistan and Myanmar (Mukhopadhyay and Ghosh, 2007). Its total production from different water bodies of Bangladesh is only 150mt (FRSS, 2009). Its production can be increased through culture

Correspondence E-mail :- nasif.sarowar@gmail.com 
practice but sufficient number of fry and fingerlings of this catfish is, however, quite difficult to obtain from natural waters for stocking in the ponds. Added to this, the fry and juveniles of this species exhibit cannibalistic tendencies (Parameswaran et al., 1971) which creates management problem.

In spite of many advantages, very few attempts have been made to popularize its commercial culture and mass production of fry and fingerlings stands as one of the major impediments towards its aquaculture. Fry production and survival can be enhanced by feeding the broodstock with supplemental diets (Santiago et al., 1991). Vitamins are likewise needed for proper reproduction in fish; this has been documented for vitamin A, E and C (Sandnes et al., 1984; Watanabe, 1985; Soliman et al., 1986; Lie and MangorJensen, 1993; NRC, 1993). Dietary additives e.g. vitamin $E$ have been found to have positive effects in the growth and reproduction of fishes (Gaylord et al., 1998; McDowell, 1989). A dietary requirement of vitamin $E$ has been demonstrated in a number of fishes including salmon (Woodall et al., 1964), channel catfish (Wilson et al., 1984), bass (Kocabas and Gatlin, 1999), carp (Takeuchi et al., 1993), tilapia (Shiau and Shiau, 2001) and shing (Roy and Mollah, 2009). As a fat-soluble vitamin, it is the most effective chain-breaking, lipid-soluble antioxidant in biological membranes, where it contributes to membrane stability. A major function of vitamin $\mathrm{E}$ is to prevent peroxidation of polyunsaturated fatty acids of phospholipid and cholesterol in cellular and subcellular membranes. Aquatic animals have high levels of unsaturated fatty acids to maintain cell membrane fluidity especially at low temperatures; it is assumed that vitamin E plays an important role in this context (Blazer, 1992).

The importance of vitamin $\mathrm{E}$ in fish reproduction has been reported by many researchers (Watanabe et al., 1970; Hamre and Lie, 1995; Halver, 2002; Paul et al., 2004; Mollah et al., 2003; and Roy and Mollah, 2009). Vitamin E caused higher gonadosomatic index, larger ova, and more eggs than a control in a study on the effect of vitamin $\mathrm{E}$ on the gonad maturity of freshwater fish (Cyprinus carpio) (Gupta et al., 1987). In addition, complete spawning occurred in fish fed a diet containing vitamin E, but only partial spawning occurred in the fish fed diets without vitamin E. In a different study, Sutjaritvongsanon (1987) found better gonad development and spawning for goldfish (Carassius auratus) fed with added vitamin E. Therefore, fry production and its survival can be enhanced by feeding the brood stock with vitamin E enriched diets (Santiago et al., 1991). Taking into account the above realities the present research was undertaken to study the growth and survival of the larvae produced from $O$. pabda broodfish treated with different dietary levels of vitamin $\mathrm{E}$.

\section{MATERIALS AND METHODS}

The research work was conducted in the 16 bowls divided into four treatments in Wet Laboratory, Faculty of Fisheries, Bangladesh Agricultural University (BAU), Mymensingh. Before that the rearing and breeding of brood fish were done in the cisterns 
of the backyard hatchery, the mini hatchery cum breeding complex, located at the Southern side of the Faculty of Fisheries.

A total of 84 healthy, strong, and similar sized female fish collected from wild were selected for rearing for the research work. There were four treatments including the control (treatment $T_{1}, T_{2}, T_{3}$ and $T_{4}$ ) each with 3 replications. The female broods of treatment $T_{1}$ served as control (i.e. fed vitamin $E$ free diet) while those of treatment $T_{2}, T_{3}$ and $\mathrm{T}_{4}$ were fed with a feed having 50,100 and 150mg vitamin $\mathrm{E} / \mathrm{kg}$ feed respectively. The feed ingredients included fish meal, soybean meal, mustard oil cake, rice bran, wheat bran, vitamin mineral premix and vitamin $\mathrm{E}$ in the form of a-tocopherol acitate, marketed as E-vet powder manufactured by the ACME Laboratories Ltd. The experimental feeds were administered directly into the corresponding cisterns twice daily ad libitum. Having rearing for 90 days with the experimental diets, a total of 36 broodfish from four treatments were randomly selected for induced breeding using PG extract at a dose of 12 and $18 \mathrm{mg} / \mathrm{kg}$ body weight of male and female respectively. After injecting PG extract, both females and males were kept together treatment wise in the hapa set in a pond for spawning. Continuous water flow was maintained in the hapa with porous PVC pipes for aeration. When the breeding was completed the fertilized eggs were removed from the hapas and placed in separate trays $\left(101.6 \times 40.6 \times 12.7 \mathrm{~cm}^{3}\right)$ treatment wise for incubation. The trays were previously filled with filtered pond water to reduce the temperature difference and environmental shock. Gentle shower was maintained through porous PVC pipes for aeration of eggs. After hatching the spawn were reared with cleaned and chopped tubificid worms for 5 days before the larvae rearing experiment could be started.

The larvae rearing experiment was started with 5 days old larvae and continued for 28 days. To study the performance of the larvae produced from female broods fed with different dietary levels of vitamin E, they were reared in 16 bowls of $10 l$ capacity divided into 4 treatments e.g. $\mathrm{T}_{1}, \mathrm{~T}_{2}, \mathrm{~T}_{3}$ and $\mathrm{T}_{4}$ having 3 replications each with 100 larvae in each bowl having an average weight and length of $21.4 \pm 8.6 \mathrm{mg}$ and $13.8 \pm 2.49 \mathrm{~mm}$ respectively i.e. 10 larvae per liter.

The larvae stocked under different treatments were fed with chopped tubificid worms twice daily (0900 and 2100h) up to satiation. The bowls were cleaned twice daily to remove dirt from the bottom and half of the total water was exchanged at morning and evening. During cleaning the bowls, dead fry, if any, was removed immediately and the number was recorded. During sampling at 7 day interval, ten larvae were randomly selected from each bowl to take the length and weight. Sampling was done before the application of feed to avoid the biasness of weight due to presence of excessive feed.

After the completion of the experiment total number of larvae of each bowl was counted and the percent survival and health condition of larvae was calculated using the stated formulae. 
The temperature, dissolved oxygen (DO) and $\mathrm{pH}$ of water in each bowl under each treatment were recorded daily. Temperature was recorded by using a celsius thermometer, DO was measured by a digital DO meter (multi 340i/set, Germany) and $\mathrm{pH}$ was measured by a portable digital $\mathrm{pH}$ meter (MICRO-TEMP, $\mathrm{pH} 500$ ).

The gain in weight $(\mathrm{mg})$ and length $(\mathrm{mm})$, specific growth rate, percent length gain, percent weight gain, health condition, survival rate of larvae were tested using one-way analysis of variance $($ ANOVA). Significant results $(\mathrm{P}<0.05)$ were further tested using Duncan's Multiples Range Test (DMRT) to identify significant difference between means. The statistical analysis was performed with the aid of the computer software SPSS programme.

\section{RESULTS AND DISCUSSION}

The initial weights of the larvae stocked under different treatments i.e. $T_{1}, T_{2}, T_{3}$ and $T_{4}$ were $21.35 \pm 0.06 \mathrm{mg}, 21.40 \pm 0.08 \mathrm{mg}, 21.35 \pm 0.13 \mathrm{mg}$ and $21.40 \pm 0.08 \mathrm{mg}$ respectively while the average final weights after 28 days were found to be $419.48 \pm 12.65 \mathrm{mg}, 475.55 \pm$ $8.62 \mathrm{mg}, 609.13 \pm 15.20 \mathrm{mg}$ and $316.75 \pm 17.19 \mathrm{mg}$ in the respective treatments (Table 1 ). The weight gain trend (Fig. 1) of the larvae of different treatments shows that the highest gain in weights of the larvae was $587.78 \pm 15.27 \mathrm{mg}$ in treatment $\mathrm{T}_{3}$ followed by $454.15 \pm 8.60$ $\mathrm{mg}$ in treatment $\mathrm{T}_{2}, 398.13 \pm 12.62 \mathrm{mg}$ in treatment $\mathrm{T}_{1}$ and $295.35 \pm 17.21 \mathrm{mg}$ in treatment $\mathrm{T}_{4}$. The highest specific growth rate (\%SGR) was also observed to be $30.36 \pm 0.12$ in treatment $T_{3}$ followed by treatment $T_{2}(29.13 \pm 0.09)$, treatment $T_{1}(28.51 \pm 0.15)$ and treatment $\mathrm{T}_{4}(27.08 \pm 0.28)$. The weight gain, percent weight gain and specific growth rate (\% SGR) were significantly $(\mathrm{P}<0.05)$ higher in treatment $\mathrm{T}_{3}$ compared to those of treatment $\mathrm{T}_{1}, \mathrm{~T}_{2}$ and $\mathrm{T}_{4}$.

Table 1. Weight gain, percent weight gain and specific growth rate (\% SGR) of larvae of O. pabda during 21 days experiment under different doses of vitamin $\mathrm{E}$ (Mean weight, $\mathrm{mg} \pm \mathrm{SD}$ )

\begin{tabular}{c|c|c|c|c|c}
\hline Treatment & $\begin{array}{c}\text { Initial weight } \\
(\mathrm{mg})\end{array}$ & $\begin{array}{c}\text { Final weight } \\
(\mathrm{mg})\end{array}$ & $\begin{array}{c}\text { weight gain } \\
(\mathrm{mg})\end{array}$ & weight gain $\%$ & SGR (\%) \\
\hline $\mathrm{T}_{1}$ & $21.35 \pm 0.06$ & $419.48 \pm 12.65$ & $398.13 \pm 12.62^{\mathrm{c}}$ & $1864.70 \pm 56.82^{\mathrm{c}}$ & $28.51 \pm 0.15^{\mathrm{c}}$ \\
$\mathrm{T}_{2}$ & $21.40 \pm 0.08$ & $475.55 \pm 8.62$ & $454.15 \pm 8.60^{\mathrm{b}}$ & $2122.18 \pm 38.48^{\mathrm{b}}$ & $29.13 \pm 0.09^{\mathrm{b}}$ \\
$\mathrm{T}_{3}$ & $21.35 \pm 0.13$ & $609.13 \pm 15.20$ & $587.78 \pm 15.27^{\mathrm{a}}$ & $2753.30 \pm 81.91^{\mathrm{a}}$ & $30.36 \pm 0.12^{\mathrm{a}}$ \\
$\mathrm{T}_{4}$ & $21.40 \pm 0.08$ & $316.75 \pm 17.19$ & $295.35 \pm 17.21^{\mathrm{d}}$ & $1380.23 \pm 82.48^{\mathrm{d}}$ & $27.08 \pm 0.28^{\mathrm{d}}$ \\
\hline
\end{tabular}

Values in the column with different superscripts are significantly $(\mathrm{P}<0.05)$ different

On the other hand, the average initial lengths of the fry were $13.75 \pm 0.24 \mathrm{~mm}, 13.83 \pm 0.10$ $\mathrm{mm}, 13.73 \pm 0.10 \mathrm{~mm}$ and $13.78 \pm 0.05 \mathrm{~mm}$ respectively in treatment $\mathrm{T}_{1}, \mathrm{~T}_{2}, \mathrm{~T}_{3}$ and $\mathrm{T}_{4}$ while the final average lengths of the fry were $55.38 \pm 3.91 \mathrm{~mm}, 64.68 \pm 2.01 \mathrm{~mm}, 86.70 \pm 1.84 \mathrm{~mm}$ and $43.18 \pm 1.73 \mathrm{~mm}$ in the respective treatments (Table 2). The highest length gain was found to be $72.98 \pm 1.81 \mathrm{~mm}$ in the fish under treatment $\mathrm{T}_{3}$ while the lowest was observed 
to be $29.40 \pm 1.70$ in treatment $\mathrm{T}_{4}$. Statistical analysis showed that both length gain and percent length gain were significantly $(\mathrm{P}<0.05)$ higher in treatment $\mathrm{T}_{3}$ compared to those of treatment $\mathrm{T}_{1}, \mathrm{~T}_{2}$ and $\mathrm{T}_{4}$.

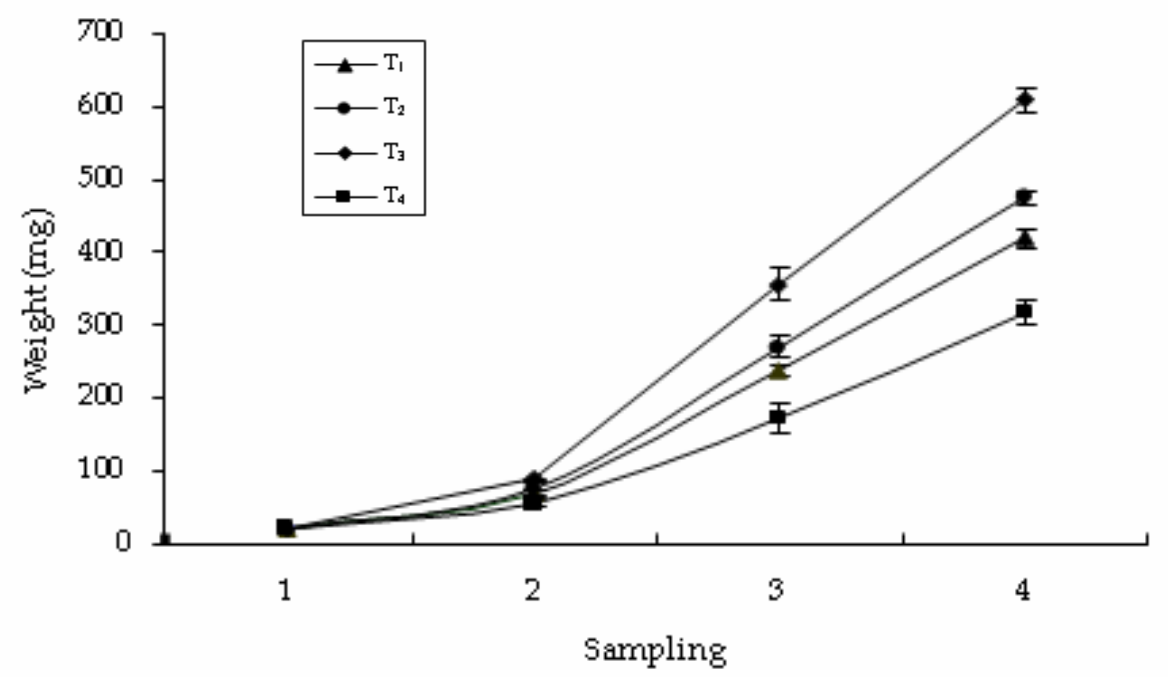

Fig. 1. Weights of larvae of $O$. pabda produced from broodfish reared under different dietary levels of vitamin E. Sampling was done at 7 days interval (Vertical bars $= \pm S D$ )

Table 2. Length gain, percent length gain, health condition and survival (\%) of larvae of O. pabda during 21 days experiment under different doses of vitamin E (Mean weight, $\mathrm{mm} \pm \mathrm{SD}$ )

\begin{tabular}{c|c|c|c|c|c|c}
\hline Treatment & $\begin{array}{c}\text { Initial length } \\
(\mathrm{mm})\end{array}$ & $\begin{array}{c}\text { Final length } \\
(\mathrm{mm})\end{array}$ & $\begin{array}{c}\text { length gain } \\
(\mathrm{mm})\end{array}$ & Length gain\% & $\begin{array}{c}\text { Health condition } \\
(\mathrm{mg} / \mathrm{mm})\end{array}$ & Survival (\%) \\
\hline $\mathrm{T}_{1}$ & $13.75 \pm 0.24$ & $55.38 \pm 3.91$ & $41.63 \pm 3.84$ & $302.70 \pm 26.72^{\mathrm{c}}$ & $10.35 \pm 1.31^{\mathrm{b}}$ & $71.00 \pm 2.16^{\mathrm{b}}$ \\
$\mathrm{T}_{2}$ & $13.83 \pm 0.10$ & $64.68 \pm 2.01$ & $50.85 \pm 1.95$ & $367.78 \pm 12.59^{\mathrm{b}}$ & $11.56 \pm 0.84^{\mathrm{b}}$ & $71.75 \pm 4.03^{\mathrm{b}}$ \\
$\mathrm{T}_{3}$ & $13.73 \pm 0.10$ & $86.70 \pm 1.84$ & $72.98 \pm 1.81$ & $531.69 \pm 12.54^{\mathrm{a}}$ & $16.63 \pm 0.69 \mathrm{a}$ & $83.25 \pm 2.87^{\mathrm{a}}$ \\
$\mathrm{T}_{4}$ & $13.78 \pm 0.05$ & $43.18 \pm 1.73$ & $29.40 \pm 1.70$ & $213.41 \pm 11.86^{\mathrm{d}}$ & $7.68 \pm 0.46^{\mathrm{d}}$ & $58.50 \pm 4.80^{\mathrm{d}}$ \\
\hline
\end{tabular}

Values in the column with different superscripts are significantly $(\mathrm{P}<0.05)$ different

The highest health condition and survival rate of the larvae were $16.63 \pm 0.69 \mathrm{mg} / \mathrm{mm}$ and $83.25 \pm 2.87$ respectively also found in treatment $\mathrm{T}_{3}$ which was significantly $(\mathrm{P}<0.05)$ different from those of other three treatments while the poorest were observed to be 7.68 $\pm 0.46 \mathrm{mg} / \mathrm{mm}$ and $58.50 \pm 4.80$ respectively in treatment $\mathrm{T}_{4}$. The Physico-chemical parameters of water in bowls under different treatments i.e. temperature, $\mathrm{pH}$ and dissolved oxygen during the experimental period ranged between 27.52 and $28.55^{\circ} \mathrm{C}, 7.05$ and $7.25,5.7$ and $6.07 \mathrm{mg} / \mathrm{l}$ respectively. 
The broodfish treated with $100 \mathrm{mg}$ vitamin $\mathrm{E} / \mathrm{kg}$ feed showed significant difference among means of all treatments in case of length gain, percent length gain, weight gain, percent weight gain, specific growth rate, health condition and survival of larvae when compared with those treated with $0 \mathrm{mg}, 50 \mathrm{mg}$ and $150 \mathrm{mg}$ vitamin E/ $\mathrm{kg}$ of feed. Similar results were observed by Mollah et al. (2009) where the larvae of Clarias batrachus produced from female broods fed with 100mg vitamin E/ $\mathrm{kg}$ feed performed better compared to other feeding doses. King et al. (1985) observed that the use of vitamin $\mathrm{E}$ in the diet of rainbow trout (Salmo gairdneri) had a significant effect on the final levels of atocopherol in eggs than fish deprived vitamin E. They further added that during egg development, a-tocopherol slowly but efficiently transferred from the yolk to the developing embryo and the mortalities during egg development were inversely related to a-tocopherol content of the eggs. This may be because vitamin $\mathrm{E}$ is an essential nutrient for all species of animals (McDowell, 1989). As a fat-soluble vitamin, it supports as an effective chain-breaking, lipid-soluble antioxidant in biological membranes, where it contributes to membrane stability. It protects critical cellular structures against damage from oxygen free radicals and reactive products of lipid peroxidation.

The better performance of larvae produced from vitamin $\mathrm{E}$ treated female broods compared to the control may be due to the fact that vitamin $\mathrm{E}$ is known to have a profound effect on the immune response of the younger fishes (Lygren et al., 2001; Lygren et al., 2000) which may enable them to grow faster. However, poor performance of the larvae of higher dosed female broods may be related to the activity of protein kinase $C$ (PKC). It is reported that excess amount of vitamin E arrests the somatic growth by inhabiting the function of PKC in vascular smooth muscle cells leading to growth arrest (Boscoboinic et al., 1991).

Stocking density is recognized as an important factor which directly affects the growth, survival and production of fish (Backiel and Le Cren, 1978). Generally higher stocking density results in the reduction of growth and survival and increases food conversion ratio (FCR), together with severe competition for food and space (Powell, 1972). During larval rearing 10 larvae/1 were stocked to ensure the better environment. This was chosen because Mollah (1991) after a detailed study on stocking density of larvae of Clarias batrachus recommended the density of 12 larvae/1 to obtain better growth and survival. Tubificid worms were used for larval rearing of O. pabda because Yasmin et al. (1998) found Tubificid worms as the best diet for larval rearing of catfish. Tubificid worms had also been reported as the most suitable live food for some other indigenous and exotic catfishes of similar nature (Haque and Barua, 1989; Mollah et al., 1998).

Dietary vitamin E treatment of broodfish of $O$. pabda has been found to have positive impact on the produced larvae in terms of growth and survival. However, it seems important to conduct experiments of similar nature to investigate the quantitative retention of vitamin $\mathrm{E}$ in the larvae and its (vitamin E) mode of action on gonad to understand the function and characterization. The success obtained through this work can serve as an important base for future research on this topic. 


\section{REFERENCES}

Backiel, T. and Le Cren, E. D. 1978. Some density relationship for population parameters. In: S. D. Gerking (ed), The biological basis of freshwater fish production. Black Well Scientific Publications: Oxford, 27-36 p.

Blazer, V. S. 1992. Nutrition and disease resistance in fish. Annu. Rev. Fish Dis., 2: 309-323.

Boscoboinic, D., Szewczyk, A., Hensey, C. and Azzi, A. 1991. Inhibition of cell proliferation by atocopherol. Role of protein kinase C. J. Biol. Chem., 266: 6188-6194.

FRSS, 2009. Fisheries Resources Survey System. Department of Fisheries, Bangladesh, 49 p.

Gaylord, T. B., Rawles, S. D., and Gatlin III, D. M. 1998. Re-evaluation of Vitamin E supplementation of practical diets for channel catfish, Ictalurus punctatus production. Aquac. Nutr., 4: 109-114.

Gupta, S. D., Khan, H. A. and Bhowmick, R. M. 1987. Observations on the effect of vitamin E and growth hormone on the gonadal maturity of carps. J. In. Fish. Soc. India. 19(2): 26- 31.

Halver, J. E. 2002. The vitamins. In: Halver, J. E., Hardy, R. W. (Eds.), Fish Nutrition. Academic Press, San Diego, CA, 61-141 p.

Hamre, K. and Lie, O. 1995. Minimum requirement of vitamin E for Atlantic salmon (Salmo salar ) at first feeding. Aqua. Res., 26: 175- 184.

Haque, M. M. and Barua, G. 1989. Rearing of shingi (Heteropneustes fossilis Bloch) fry under laboratory condition. II. Feeding and growth of fry. Bangladesh J. Fish., 12(1): 67-72.

King, I., Hardy, R. W., and Halver, J. E. 1985. The effect of dietary vitamin E on the distribution of a-tocopherol in rainbow trout (Salmo gairdneri) during ovarian maturation. In: Ivamoto, R. N., Sower, S. (Eds.), International Symposium on Salmonid Reproduction Ced. Washington Sea Grant Program University of Washington, Seatle WA, 111- 112 p.

Kocabas, A. M. and Gatlin, D. M. 1999. Dietary vitamin E requirement of hybrid striped bass (Morone chrysops female $\times$ M. saxatilis male). Aquaculture Nutr., 5: 3-7.

Lie, O. and Mangor-Jensen, A. 1993. Importance of broodstock nutrition for optimal production in aquaculture. In: Fish farming technology. Eds: H. Reinertsen, L. A. Dahle, L. Jorgensen and K. Tvinnereim. Proc. 1st Int. Conf. Fish Farming Techn., Trondheim, Norway, 9-12 August 1993. Rotterdam, Netherlands: A. A. Balkema, 35-40 p.

Lygren, B., Hamre, K. and Waagbo, R. 2000. Effect of induced hyperoxia on the antioxidant status of atlantic salmon Salmo salar L. fed three different levels of dietary vitamin E. Aqua. Res., 31: 401-407.

Lygren, B., Hjeltnes, B. and Waagbo, R. 2001. Immune response and disease resistance in Atlantic salmon (Salmo salar L.) fed three levels of dietary vitamin $\mathrm{E}$ and the effect of vaccination on the liver status of antioxidant vitamins. Aqua. Intl., 9: 401-411.

McDowell, L. R. 1989. Vitamin E. In: Vitamins in animal nutrition: comparative aspects to human nutrition. San Diego: Academic Press, 93 p.

Mollah, M. F. A. 1991. Effects of stocking density on growth and survival of catfish (Clarias batrachus L.) larvae. Bangladesh J. Fish., 14(1\&2): 57-62.

Mollah, M. F. A., Khan, M. M. R. and Haylor, G. S. 1998. Effects of different feeds on growth and survival of African catfish (Clarias gariepinus). Bangladesh J. Agril. Sci., 25(2): 159-162.

Mollah, M. F. A., Roy, A. and Mamun, M. S. A. 2009. Growth performance of larvae produced from vitamin E treated female Clarias batrachus (Linnaeus). Prog. Agril., 7(2): 425-430. 
Mollah, M. F. A., Sarder, M. R. I. and Begum, T. 2003. Effects of different dietary levels of vitamin E on the breeding performance of Heteropneustes fossilis (Bloch). Bangladesh J. Fish. Res., 7(1): $11-20$.

Mukhopadhyay, T. and Ghosh, S. 2007. Lipid profile and fatty acids composition of two silurid fish eggs. J. Oleo. Sci., 56(8): 399-403.

NRC (National Research Council), 1993. Nutrient requirements of fish. National Academic Press, Washington DC.

Parameswaran, S., Selvaraj, C. and Radhakrishnan, S. 1971. Notes on the life-history and biology of the Catfish Ompok pabda (Hamilton). J. Zoo1. Soc. India. 23(2): 137-150.

Paul, B. N., Sarkar, S. and Mohanty, S. N. 2004. Dietary vitamin E requirement of mrigal, Cirrhinus mrigala fry. Aquaculture, 242: 529-536.

Powell, M. R. 1972. Cage and raceway culture of stripped bass in brackish water in Alabama. Proc. $2^{\text {th }}$ Ann. Conf. South-east Assoc. Game Fish Comn., 553 p.

Roy, A. and Mollah, M. F. A. 2009. Effects of different dietary levels of vitamin E on the ovarian development and breeding performances of Clarias batrachus (Linnaeus). J. Bangladesh Agril. Univ., 7(1): 183-191.

Sandnes, K., Ulgenes, Y., Braekkan, O. R. and Utne, F. 1984. The effect of ascorbic acid supplementation in broodstock feed for reproduction of rainbow trout (Salmo gairdneri). Aquaculture, 43: 167-177.

Santiago, C. B., Camacho, A. S. and Laron, M. A. 1991. Growth and reproductive performance of bighead carp (Aristichthys nobilis) reared with or without feeding in floating cages. Aquaculture, 96: 109-117.

Shiau, S. Y. and Shiau, L. F. 2001. Re-evaluation of the vitamin E requirements of juvenile tilapia, Oreochromis niloticus $\times$ O. aureus. Anim. Sci., 72: 529-534.

Siddiqua, K. A., Islam, M. S., Hossain, M. G. and Ahmed, A. T. A. 2000. A histological study of the spermatogenesis in Ompok pabda (Hamilton-Buchanan 1822). Bangladesh J. Fish. Res., 4(2): 185-189.

Soliman, A. K., Jauncey, K. and Roberts, R. J. 1986. The effect of dietary ascorbic acid supplementation on hatchability, survival and fry performance in Oreochromis mossambicus Peters. Aquaculture, 59: 197-208.

Sutjaritvongsanon, S. 1987. Level of vitamin E content suitable for gonad developing and spawning of goldfish, Carassius auratus (Linnaeus). Abstracts of Master of Science Thesis Fisheries Science, Notes Fac. Fish. Kasetsart Univ., Bangkok, No. 12, 2 p.

Takeuchi, T., Watanabe, K., Satoh, S. and Watanabe, T. 1993. Requirement of grass carp fingerlings for a-tocopherol. Nip. Sui. Gakk., 58: 1743-1749.

Watanabe, T. 1985. Importance of the study of broodstock nutrition for further development of aquaculture. In: Nutrition and feeding in fish. Eds: C. B. Cowey, A. M. Mackie and J. G. Bell. London: Academic Press, 395-414 p.

Watanabe, T., Takashima, F., Ogino, C. and Hibiya, T. 1970. Requirements of young carp for atocopherol. Bull. Jpn. Soc. Sci. Fish., 36: 972- 976.

Wilson, R. P., Bowser, P. R. and Poe, W. E. 1984. Dietary vitamin E requirement of fingerling channel catfish. J. Nutr., 114: 2053- 2058.

Woodall, A. N., Ashley, L. M., Halver, J. E., Olcott, H. S. and Van Der Veen, 1964. The a-tocopherol requirement of chinook salmon. J. Nutr., 84: 125-135.

Yasmin, A., Mollah, M. F. A. and Hylor, G. S. 1998. Rearing of catfish (Clarias batrachus) larvae with live and prepared feeds. Bangladesh J. Fish. Res., 2(1): 41-46. 